\title{
大腸粘液癌の臨床病理学的検討
}

\author{
埼玉県立がんセンター腹部外科 \\ 鈴木 章一 関根 毅 須田 雍夫
}

\section{CLINICOPATHOLOGICAL STUDIES OF MUCINOUS CARCINOMA OF THE COLON AND RECTUM}

\author{
Shoichi SUZUKI, Takeshi SEKINE and Yasuo SUDA \\ Abdominal Surgery Clinic, Saitama Cancer Center Hospital
}

\begin{abstract}
大腸粘液癌症例は大腸癌手術例482例中 23 例，4.8\%にみられた。この5ち, 大腸粘液癌妡除症例 22 例について臨床病理学的検討を分化型腺癌症例 377 例と対比し行った。粘液癌は若年者, 女に多い傾向 がみられ，占居部位では盲腸に有意に多く認められた $(\mathrm{p}<0.05)$. 肉眼型では 3 型が多くみられた。 stage は進行したものが多く, 壁深達度は $\mathrm{ss}\left(\mathrm{a}_{1}\right)$ 以上, リンパ節転移は $\mathrm{n}_{3}(+), \mathrm{n}_{4}(+) か ゙$ 多い傾向を 示した。腹膜転移は $18.2 \%$ に認められた。治癒切除率は $60.9 \%$ で分化型腺癌に比べて低率であった。 5 年生存率は粘液癌切除例では $53.4 \%$ で分化型腺癌に比べて不良であったが，治癒切除例では $82.0 \%$ で分化型腺癌と同様であり，遠隔成績は良好であった。
\end{abstract}

索引用語：大腸粘液癌，大腸粘液癌治瘾切除，大腸粘液癌術後遠隔成績

はじめに

近年, 大腸癌に対する認識の高揚とともに診断技術 の進歩により，早期癌をはじめとする比較的早期の癌 子発見されるようになり,治療成績は向上しつつある。 しかし，大腸癌の $10 \%$ 前後を占める特異な組織像を示 す粘液癌は予後不良之されている12). 今回, われわれ は大腸粘液癌症例について, 臨床病理学的検討を分化 型腺癌と対比し行うとともに，併せて $2 ， 3$ の問題点 について考察を加觉て報告する。

\section{I. 対象および方法}

昭和 50 年 11 月から 62 年 12 月までの 12 年間に埼玉県立 がえセンター腹部外科に叔いて経験した大腸癌手術症 例は482例である. 粘液癌は大腸癌取扱い規約 ${ }^{31} に$ 従っ て, 切除標本の組織学的検索において癌巣の最大割面 で50\%以上が粘液結節で占められているものと規定し た. 大腸粘液癌症例は23例で, 大腸癌手術例全体の $4.8 \%$ 占めていた。 そして, これらのらち, 粘液癌切 除症例22例（非切除例を除く）について, 臨床病理学 的成績と遠隔成績を中心に，高分化腺癌拉よび中分化 腺癌を一括した分化型腺癌症例 377 例（高分化202例,

$<1989$ 年 7 月 10 日受理 $>$ 別刷請求先 : 関根 毅

干362 埼玉県北足立郡伊奈町小室818 埼玉県立がん センター腹部外科
中分化175例)之対比し検討した。なおこれらの検討 にあたっての用語は大腸癌取扱い規約゙によった。 た, 統計学的な有意差検定には $\chi^{2}$ 検定, 生存率の有意 差検定には Generalized Wilcoxon 法, Cox-Mantel 法, Logrank 法を用いた。

\section{II. 成 績}

1. 症例の検討一年齢および性

年齢，性についてみると，大腸粘液癌 22 例の平均年 秢は58.4筬（36〜79歳），男女比は $1: 1.1$ で，分化型 腺癌377例の平均年龃60.4歳，男女比 $1: 0.8$ に比べて 若年者, 女に多い傾向がみられたが, 有意差は認めら れなかった。

2. 臨床病理学的検討

a. 占居部位

占居部位についてみると（表 1)，粘液癌は結腸に持 いては16例, 直腸一肛門管においては 6 例にみられた。 結腸癌では右側結腸（C～T）は10例，5ち盲腸（C) 5 例, 上行結腸 (A) 3 例, 横行結腸 (T) 2 例で, 左 側結腸 (D S) は 6 例， 万ち下行結腸 (D) 2 例, S 状 結腸 (S) 4 例であった。一方，直腸癌では直腸 S 状部 (Rs)，下部直腸( $\mathrm{Rb}$ )はそれぞれ 2 例，上部直腸 $(\mathrm{Ra})$ ， 肚門管 $(P)$ はそれぞれ 1 例であった。また，粘液癌と 分化型腺癌を比べると盲腸 (C) では有意差が認められ 


\begin{tabular}{|c|c|c|}
\hline 占居部位 & 分化型腺前 & 粘澭蕾 \\
\hline c & 26例 $\left(6.9^{1}\right)$ & 5 例 $(22.82))$ \\
\hline A & $29(7.7)$ & $3(13.6)$ \\
\hline $\mathbf{T}$ & $22(5.8)$ & $2(9.1)$ \\
\hline D & $11 \quad(2.9)$ & $2(9.1)$ \\
\hline s & $69(18.3)$ & $4 \quad(18.2)$ \\
\hline Rs & $36(9.6)$ & $2(9.1)$ \\
\hline Ra & $60 \quad(15.9)$ & $1 \quad(4.5)$ \\
\hline $\mathbf{R b}$ & 118 (31.3) & $2(9.1)$ \\
\hline $\mathbf{P}$ & $6 \quad(1.6)$ & $1(4.5)$ \\
\hline st & 377例 & 22例 \\
\hline
\end{tabular}

表 2 大腸癌の組織型別肉眼型

\begin{tabular}{|c|c|c|}
\hline & 分化型腺康 & 粘液满 \\
\hline 0 型 & 19例 $(5.0)$ & 0 例(0) \\
\hline 1 & $23(6.1)$ & $2(9.1)$ \\
\hline 2 & $233 \quad(61.8)$ & $10 \quad(45.5)$ \\
\hline 3 & $101 \quad(26.8)$ & $9 \quad(40.9)$ \\
\hline 4 & $1(0.3)$ & $1(4.5)$ \\
\hline 部 & 377 例 & 22例 \\
\hline
\end{tabular}

た $(\mathrm{p}<0.05)$.

b. 肉眼型

肉眼型についてみると(表 2)，粘液癌では 0 型は 1 例もみられず， 1 型は 2 例， 2 型は 10 例， 3 型は 9 例, 4 型は 1 例であった。分化型腺癌の肉眼型と相対頻度 別に比較すると, 分化型腺癌では 2 型は $61.8 \%$, 粘液 癌では 3 型は $40.9 \%$ と多く認められたが，有意差はな かった。

\section{c. 壁深達度}

壁深達度についてみると(表 3)，粘液癌では早期癌 $(\mathrm{m}, \mathrm{sm})$ は 1 例もみられず, 全例, ss $\left(\mathrm{a}_{1}\right)$ 以上の進 行癌であった。すなわち, ss $\left(\mathrm{a}_{1}\right)$ は $40.9 \%, \mathrm{~s}\left(\mathrm{a}_{2}\right)$ は $31.8 \%$, si (ai) $27.3 \%$ にられ，粘液癌における si (ai) の頻度は分化型腺癌 $13.0 \%$ の約 2 倍であったが, 有意差は認められなかった。

\section{d. リンパ節転移}

組織型別のリンパ節転移についてみると(表 4 ), 粘 液癌のリンパ節転移恃 $50.0 \%$ で，分化型腺癌の $44.9 \%$ と汪涪同様であった。しかし， $\mathrm{n}_{1}(+)$ および $\mathrm{n}_{2}(+)$ では粘液癌，分化型腺癌のいずれでも同様の転移率を 示したのに対して, $\mathrm{n}_{3}(+)$ および $\mathrm{n}_{4}(+)$ では粘液癌
表 3 大腸癌の組織型別壁深達度

\begin{tabular}{|c|c|c|}
\hline & 分化型腺密 & 粘 液䕱 \\
\hline$m$ & 14例(3.7) & 0 例 $(0)$ \\
\hline sm & $8 \quad(2.1)$ & $\begin{array}{ll}0 & (0)\end{array}$ \\
\hline $\mathrm{pm}$ & $38 \quad(10.0)$ & $0 \quad(0)$ \\
\hline $\operatorname{ss}\left(a_{1}\right)$ & $149 \quad(39.5)$ & $9 \quad(40.9)$ \\
\hline $\mathbf{s}\left(\mathbf{a}_{2}\right)$ & $119 \quad(31.7)$ & $7 \quad(31.8)$ \\
\hline si (ai) & $49 \quad(13.0)$ & $6 \quad(27.3)$ \\
\hline 計 & 377例 & 22例 \\
\hline
\end{tabular}

表 4 大腸癌の組織型別リンパ節転移

\begin{tabular}{|c|c|c|}
\hline & 分化型腺嵒 & 粘 液 型 \\
\hline$n(-)$ & 208例 (55.1) & 11 例 $(50.0)$ \\
\hline$n_{1}(+)$ & $73 \quad(19.4)$ & $3 \quad(13.6)$ \\
\hline $\mathrm{n}_{2}(+)$ & $68 \quad(18.0)$ & $4 \quad(18.2)$ \\
\hline$n_{3}(+)$ & $18(4.8)$ & $2(9.1)$ \\
\hline$n_{4}(t)$ & $10(2.7)$ & $2(9.1)$ \\
\hline 部 & 377例 & 226 例 \\
\hline
\end{tabular}

においてそれぞれ9.1\%，9.1\%であり，分化型腺癌の それぞれ $4.8 \% ， 2.7 \%$ に比べてリンパ節転移は高率で あった。しかし、リンパ節転移に招いて，粘液癌と分 化型腺癌の間に有意差はみられなかった。

e. 肝転移拈よび腹膜転移

肝転移阮よび腹膜転移についてみると(表 5 ), 粘液 癌において肝転移は 3 例，腹膜転移は 4 例に認められ た。そして, 粘液癌と分化型腺癌との対比では肝転移 は注济同様であったが, 腹膜転移は分化型腺癌の $9.8 \%$ に対して粘液癌では $18.2 \%$ にみられた。しかし，肝転 移および腹膜転移において粘液癌と分化型腺癌との間 に有意差は認められなかった。

\section{f. 脈管侵襲}

リンパ管侵襲（ly）についてみると（表 6)，粘液癌 では $\mathrm{ly}_{2} 40.9 \%, \mathrm{ly}_{3} 18.2 \%$ と分化型腺癌に比べてリン 八管侵襲の高度のものが多く認められた。しかし，有 意差はみられなかった。静腹侵襲 $(\mathrm{v})$ についてみると, 粘液癌, 分化型腺癌のいずれでも浪济同様の傾向を示 したが，有意差は認められなかった。

g. 組織学的進行程度 (stage) 
表 5 大腸癌の組織型別肝転移, 腹膜転移 肝転移

\begin{tabular}{|c|c|c|}
\hline & 分化型腺漶 & 粘 液重 \\
\hline$H(-)$ & 329 例(87.3) & 19例(86.4) \\
\hline$H(+)$ & $48 \quad(12.7)$ & $3 \quad(13.6)$ \\
\hline 䀒 & 377例 & 221例 \\
\hline
\end{tabular}

腹膜転移

\begin{tabular}{|c|c|c|}
\hline & 分化型腺密 & 粘液萿 \\
\hline $\mathbf{P}(-)$ & 340 例 $(90.2)$ & 18例 (81.8) \\
\hline$P(+)$ & $37 \quad(9.8)$ & $4(18.2)$ \\
\hline lif & 377例 & 22 (99 \\
\hline
\end{tabular}

表 6 大腸癌の組織型別脈管侵裂

\begin{tabular}{|c|c|c|c|}
\hline \multicolumn{4}{|c|}{ リンパ管侵靚 } \\
\hline & \multicolumn{2}{|c|}{ 分化型腺癌 } & 粘 湾亚 \\
\hline $\mid y_{0}$ & 102 B & N(27.1) & 3例 $(13.6)$ \\
\hline $\mid \mathbf{y}_{1}$ & 153 & $(40.6)$ & $6 \quad(27.3)$ \\
\hline$y_{2}$ & 93 & $(24.6)$ & $9(40.9)$ \\
\hline $\mathrm{Iy}_{3}$ & 29 & $(7.7)$ & $4(18.2)$ \\
\hline 尌 & 3779 & & 22 俰 \\
\hline
\end{tabular}

踭脈侵要

\begin{tabular}{|c|c|c|}
\hline & 分化型腺菚 & 粘 液痒 \\
\hline$v_{0}$ & 102例(27.1) & 5例 (22.7) \\
\hline$v_{1}$ & $137 \quad(36.3)$ & $7(31.8)$ \\
\hline$v_{2}$ & $115 \quad(30.5)$ & $8 \quad(36.5)$ \\
\hline \multirow[t]{2}{*}{$v_{3}$} & $23(6.1)$ & $2(9.0)$ \\
\hline & 377例 & 22倒 \\
\hline
\end{tabular}

粘液癌における stage（表 7)では, stage II は $31.8 \%$ ( 7 例), stage III は27.3\% (6 例), stage IV は13.6\% ( 3 例), stage V は27.3\%（6 例）であり, 分化型腺癌に比べて stage の進行した症例が多くみら れる傾向を示した. しかし, 各 stageに扎いて粘液癌と 分化型腺癌との間に有意差はみられなかった。また， stage Iは 1 例も認められなかった。

h. 手術別頻度

手術別頻度についてみると(表 8)，粘液癌では治痹 切除は $60.9 \%$ (14例), 非治癒切除は $34.8 \%$ ( 8 例), 非切除は $4.3 \%$ （1 例）で，治痹切除率60.9\%は分化型 腺癌の $70.0 \%$ に比べて低率であった。 また，粘液癌の 非治瘾切除 8 例に打ける非治瘾因子は, 腹膜転移 $(\mathrm{P})$ 4 例, 肝転移 $(\mathrm{H}) 2$ 例, 腹膜転移と肝転移の複合 $(\mathrm{P}+$ $\mathrm{H})$ など 2 例であり，これらのうち，腹膜転移 $(\mathrm{P})$ が 大部分を占めていた。
表 7 大腸癌の組織型別 stage

\begin{tabular}{|c|c|c|}
\hline & 分化型滕勧 & 粘 液袖 \\
\hline stage I & 58 例 (15.4) & 0 例 $(0)$ \\
\hline II & $123 \quad(32.6)$ & $(31.8)$ \\
\hline III & $75 \quad(19.9)$ & (27.3) \\
\hline IV & $55 \quad(14.6)$ & $(13.6)$ \\
\hline $\mathrm{v}$ & $66 \quad(17.5)$ & (27.3) \\
\hline 形 & 3776 & 228 \\
\hline
\end{tabular}

表 8 大腸癌の手術別頻度

\begin{tabular}{|c|c|c|}
\hline & 分化型腺艁 & 耛夜 雷 \\
\hline 治憲切除 & 279 例 $(70.0)$ & 14例 $(60.9)$ \\
\hline 非治䨩切除 & $98 \quad(24.5)$ & $8 \quad(34.8)$ \\
\hline 非切除 & $23(5.5)$ & $1(4.3)$ \\
\hline It & 400 (19) & 23将! \\
\hline
\end{tabular}

さらに, 粘液癌を粘液結節内の腺癌部における分化 度で高分化型粘液癌上中分化および低分化型粘液癌に 分類し検討してみた。すすなわち，高分化型粘液癌では 2 例中 2 例に肝転移 $(\mathrm{H})$ ，中分化および低分化型粘液 癌では 6 例の5ち，腹膜転移 (P) は 4 例，腹膜転移と 肝転移の複合 $(\mathrm{P}+\mathrm{H})$ は 2 例にみられ，前者は肝転移， 後者は腹膜転移が高率に認められた。

\section{3. 遠隔成績}

大腸癌切除例(耐術症例)（粘液癌22例, 分化型腺癌 377例）における生存曲線についてみると（図 1)，分 化型腺癌の生存曲線はなだらかに下降し， 3 および 5

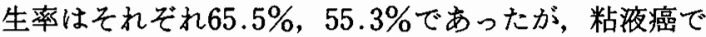
は術後 1 年間に生存曲線㴔峻に下降し， 3 生率は $53.4 \%$ ですでに分化型腺癌の 5 生率より低率であっ た。しかし， 3 および 5 生率に打いて分化型腺癌と粘 液癌の間に有意差はみられなかった。一方，治瘾切除 例（分化型腺癌279例, 粘液癌14例）についてみると, 3 および 5 生率は分化型腺癌ではそれぞれ79.7\%，

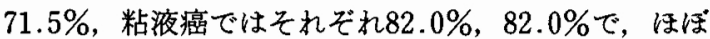
同様の成績を示し，両者の間に有意差は認められな かった。

\section{III. 考 察}

大腸粘痹癌は特異な組織像之臨床病理学的特徵を有 し，欧米では多数例の検討がなされている。しかし， わが国では弥政らかの報告をはじめ散見されるにすぎ ない. 
図 1 大腸癌切除例一生存曲線一 (Kaplan-Meier 法) 切除例

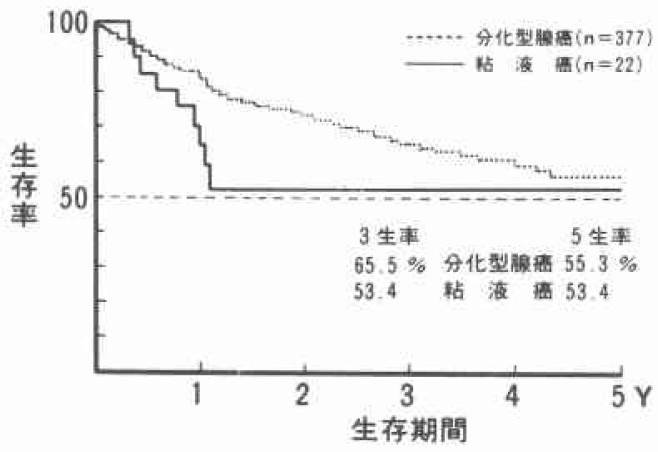

治瘁切除例

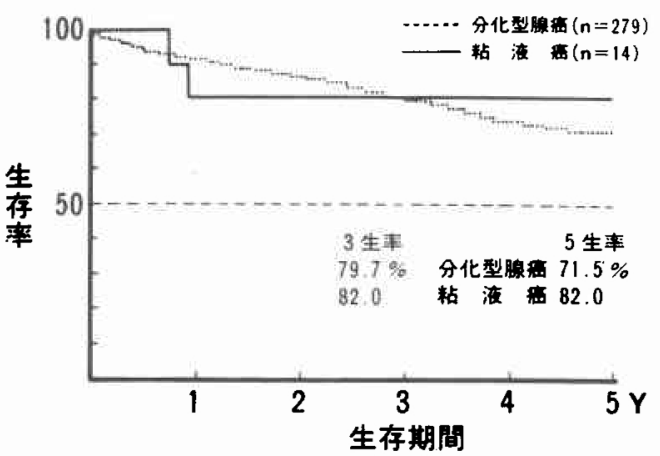

粘液癌の定義は報告者によって必ずしも一定してい ない.ちなみに, Symonds ら ${ }^{11}$, Umpleby 55), 弥政 ら 4)は切除標本の最大割面において特異な組織像を示 す粘液塊が $60 \%$ 以上を占めるすのとしている.われわ れは大腸癌取扱い規約 $\left.{ }^{3}\right)$ 従って, 腺湶細胞の粘液産 生が高度で，粘液は結節状を呈して貯溜(mucous nodule あるいは mucous lake)し，癌細胞は不完全な腺腔 を形成して粘液中に浮遊するかあるいは粘液結節の辺 縁に存在する組織像が癌全体の50\%以上を占めたもの を粘液癌とした。

大腸粘液癌の頻度はわが国では6.0〜 $11.4 \%{ }^{2) 6) \sim 8)}$, 欧米では8.2〜 $16.6 \%{ }^{5) 9) 10)}$ と $10 \%$ 前後の報告がなされ ているが，粘液癌の定義によっても異なるものと思わ れる. 自験例の検討では大腸粘液癌の頻度は大腸癌手 術例全体の $4.8 \%$ であった。 大腸粘液癌は性別では女， 年齢では若年者に多いとされているが4) 6)8) 10), 自験 例でも同様の傾向であった，年龄についてみると，大 腸粘液癌の平均年齢は能見 $5^{8)} 52.5$ 歳, Trimpi $5^{9)}$ 55.4 歳, Wolfman $5^{10} 57.6$ 歳と報告して扣り, 自験例
の58.4歳とほぼ同様であった。しかし, Recalde ら ${ }^{11}$ 柱 35 歳以下の大腸癌 40 例の検討に拈いて, 粘液癌が 12 例, 30\%にみられたとしている.

大腸粘液癌の占居部位は結腸では盲腸 (C), S 状結 腸 $(\mathrm{S})$ ，直腸では直腸 $\mathrm{S}$ 状部 (Rs)，下部直腸 (Rb) に多くみられ，自験例の検討では高ら ${ }^{12)}$ の指摘する大 腸の左右両端にみられたとする報告と同様であった が， とくに盲腸 (C) に和いて高率であり，分化型腺癌 に比べて有意差が認められた $(\mathrm{p}<0.05)$. 肉眼型は浸 潤潰瘍型が $45.7 \%$ と多くみられたとする奥野ら ${ }^{13)}$ の成 績と同様であったが，決潰の少ない隆起を主体とする 病変で, 表面の性状が多結節性, 細顆粒状を呈する場

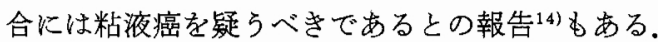

組織学的進行程度 (stage) では大腸粘液癌は分化型 腺癌に比べて進行した症例が有意に多いとされてい る. 粘液癌の壁深達度は自験例の検討では m, sm, pm は 1 例もなく, 全例, ss（ $\mathrm{a}_{1}$ ) 以上の進行癌であった。 また，si（ai）は分化型腺癌に比べて約 2 倍の頻度を示 した.このことは粘液癌は管外性に粘液胞を形成する ことが多いために, 症状発現が遅く進行した状態では じめて発見されることが多いことる裏付けるわのであ ろう。このことに関して, Trimpi ら"1は粘液癌の局所 に打ける浸潤機構として, 粘液癌が水分を吸収, 膨化 することにより組織間隙が生じ, 癌細胞の払大を容易 にする可能性を挙げている，粘液癌のリンパ節転移で は, 奥野ら ${ }^{13)}$ は74.3\%, Sundblad ら ${ }^{15)} 43.0 \%$ と報告 し，いずれも分化型腺癌に比べて高率であったとして いる. 自験例の検討ではリンパ節転移に和いて粘液癌 と分化型腺癌との間に有意差はみられなかったが，粘 液癌に打ける $\mathrm{n}_{3}(+)$ 打よび $\mathrm{n}_{4}(+)$ は分化型腺癌の 2 倍の頻度を示したことは注目される。粘液癌の肝転移 は分化型腺癌と同様であったが，腹膜転移は 2 倍の頻 度であった。このことは奥野ら ${ }^{13)}$, 弥政ら ${ }^{4)}$ 指摘する ごとく, 粘液癌の特幑として腹膜転移 (P) 陽性率が高 いことを示するのであろう。屯た，大腸粘液癌症例に おいて, 前述のごとく, 粘液癌を粘液結節内の腺癌部 の分化度で高分化型粘液癌と中分化执よび低分化型粘 液癌に亜分類し検討することも今後，重要なことと思 われる(4)7.

一方，大腸粘液癌の遠隔成績についてみると，自験 例の検討では切除例において術後 1 年間でその生存曲 線は急峻に下降して，1生率は53.4\%とすでに分化型 腺癌の 5 生率よりも低率で, 遠隔成績は不良であった。 しかし，治癒切除例においては 3 および 5 生率は粘液 
癌ではそれぞれ $82.0 \%, 82.0 \%$ ，分化型腺癌ではそれ ぞれ79.7\%，71.5\%で，両者の間に有意差はみられな かったが，汇ぼ同様の成績を示し，遠隔成績は良好で あった，粘液癌の予後については, 非粘液癌と比べて 差がみられないとする報告9)や良好とする報告 ${ }^{16)}$ あ るが，予後不良とする報告(12)688)133が多い，ちなみに， 広田ら 21 は治癒切除例における累積 5, 10生率は分化 型腺癌ではそれぞ机 $68.1 \%, 60.6 \%$, 粘液癌では $40.6 \% ， 31.6 \%$ であり, 統計学的に有意差がみられた としている。㐬たわれわれは症例数が少ないために 粘液癌症例を結腸癌と直腸癌に分けて検討しなかった が，とくに直腸粘液癌においては遠隔成績は不良とさ れている(1)677. このことに関して, Symonds ら ${ }^{11}$ は直腸 粘液癌では局所再発が高率にみられたとしている。わ れわれは大腸粘液癌症例の遠隔成績の検討から, 手術 に際しては，広範なリンパ節郭清とともに，可及的に 合併切除を含む主病巣の広範囲切除により治瘾切除を 施行すべきである。また，非治瘾切除例に扔いては， より有効な抗癌剂の選択, 投与が必要と思われる.

\section{結 語}

大腸粘液癌切除症例 22 例について, 臨床病理学的検 討を分化型腺癌症例 377 例と対比し行い, 以下の結論を 得た。

1) 大腸粘液癌は 23 例で，大腸癌手術例全体の $4.8 \%$ を占め, このうち切除症例は22例であった。平均年齢

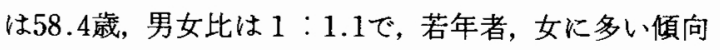
がみられた。

2）占居部位は結腸では盲腸, S 状結腸, 上行結腸に, 直腸では直腸 S 状部，下部直腸に多くみられた。とく に分化型腺癌に比べて盲腸では有意差が認められた $(\mathrm{p}<0.05)$.

3）肉眼型は分化型腺癌に比べて 3 型が多くみられ た.

4) 組織学的進行程度（stage）は進行したものが多 く, 構成因子別にみると, 壁深達度は ss $\left(a_{1}\right)$ 以上, リ ンパ節転移は $\mathrm{n}_{3}(+)$ および $\mathrm{n}_{4}(+)$ が多い傾向を示し, 腹膜転移は $18.2 \%$ に認められた。

5）脈管侵襲は分化型腺癌に比べてリンパ管侵襲で は高度 $\left(\mathrm{ly}_{2}, \mathrm{ly}_{3}\right)$ のものが多く, 静脈侵襲でも同様の 傾向であったが，いずれも有意差は認められなかった。

6）治癒切除率は60.9\%で分化型腺癌に比べて低率 であった. 非治癒因子では腹膜転移が大部分を占めて いた.

7）遠隔成績において, 粘液癌切除例では 3 および 5
年生存率はそれぞれ $53.4 \% ， 53.4 \%$ で分化型腺癌に比 べて不良であった。しかし，治瘾切除例では 3 および 5 年生存率はそれぞれ $82.0 \% ， 82.0 \%$ で分化型腺癌と ほぼ同様であり，両者の間に有意差は認められなかっ たが，遠隔成績は良好であった。

\section{文献}

1) Symonds DA, Vickery AL: Mucinous carcinoma of the colon and rectum. Cancer 37 : 1891-1900, 1976

2）広田映五, 岡田俊夫, 板橋正幸注か：大腸癌の組織 型之予後. 日臨 $39: 2108-2116,1981$

3）大腸癌研究会編：臨床・病理 大晹癌取扱い規約. 改訂第 4 版，金原出版，東京， 1985

4）弥政晋輔, 広田映五, 板橋正幸住か：大腸粘液癌の 臨床病理学的検討. 日消外会誌 $21: 75-81,1988$

5) Umpleby HC, Ranson DL, Williamson RCN : Peculiarities of mucinous colorectal carcinoma. Br J Surg 72:715-718, 1985

6) 喜納 勇, 甲田安二郎：大腸癌の病理 臨床病理. 西 满正監修. 大腸癌の臨床, へるす出版, 東京, 1984, p144-155

7）在々英達, 喜納 勇: 胃粘液癌と大腸粘液癌との 比較研究. 第 1 編 臨床病理学的研究. 日消病会誌 $76: 659-667,1979$

8）能見伸八郎, 田中承男, 井口公雄ほか：大腸粘液癌 の検討. 日消外会誌 $15 ： 1376-1380,1982$

9) Trimpi HD, Bacon HE: Mucoid carcinoma of the rectum. Cancer $4: 597-609,1951$

10) Wolfman EF, Astler VB, Coller FA: Mucoid adenocarcinomas of the colon and rectum. Surgery $42: 846-852,1957$

11) Recalde M, Holyoke ED, Elias EG: Carcinoma of the colon, rectum, and anal canal in young patients. Surg Gynecol Obstet 139: 909-913, 1974

12）高 相進, 金子慶虎, 竹村克二ほか：大腸の粘液癌 および印環細胞癌, 8 例の検討. 日本大腸肛門病会 誌 $34: 396,1981$

13）奥野匡有, 池原照幸, 長山正義はか：大腸粘液癌の 臨床病理学的特徵。日臨外医会誌 $48: 609-614$, 1987

14）三浦か括る, 吉田茂昭, 斉藤大三ほか：大腸粘液癌 の内視鏡的特徵像について. Prog Dig Endosc $29: 171-175,1986$

15) Sundblad AS, Paz RA: Mucinous carcinomas of the colon and rectum and their relation to polyps. Cancer $50: 2504-2509,1982$

16）磯野可一, 斉藤登喜男, 佐藤裕俊：直腸癌の予後に 関する病理組織学的検討一とくに胃癌との比較に おいて。癌の臨 21：905-909, 1975 